\title{
HUBUNGAN ANTARA PEMBEBANAN DENGAN PENURUNAN (DISPLECEMENT) BATA MERAH PEJAL DILIHAT DARI POSISI PEMBAKARANNYA
}

\author{
Irvin Devanty, Irza Ahmad, Daryati
}

\begin{abstract}
Abstrak
Penelitian ini bertujuan untuk mengetahui berapa besar perbedaan nilai penurunan (displacement) yang terjadi pada bata merah pejal posisi pembakaran atas, tengah dan bawah jika diberi gaya lateral. Batu bata diambil dari Lemah Abang, Cikarang. Metode yang digunakan adalah metode eksperimen. Penelitian ini dilaksanakan di Laboratorium balai Penelitian Bahan Dinas perindustrian DKI Jakarta, di Jl. Let. Jend. Suprapto, Cempaka Putih, Jakarta Pusat. Tahapan penelitian. Statistik yang digunakan adalah analisa Lilliefors untuk normalitas data, analisa Bartlett untuk homogenitas data dan ANAVA untuk menghitung perbedaan penurunan di antara tiap kelompok batu bata merah
\end{abstract}

Kata Kunci : pembebanan, penurunan

\section{PENDAHULUAN}

Salah satu program pemerintah yang sedang dikembangkan dewasa ini adalah penyediaan perumahan yang layak huni ditinjau dari segi teknis, higienis dengan biaya yang relatif murah. Lajunya pembangunan perumahan membawa dampak terhadap perkembangan industri bahan bangunan, salah satu diantaranya adalah industri bata merah.

Sebagian besar masyarakat saat ini masih menggunakan bata merah sebagai bahan bangunan yang digunakan untuk komponen dinding bangunan tingkat rendah maupun tingkat tinggi, sehingga kebutuhan bata merah pada saat ini masih tergolong tinggi.

Selama ini di Indonesia produksi bata merah masih didominasi oleh industri kecil serta proses pembuatannya masih sangat tradisional, hal ini dapat dilihat dari cara pembakaran bata merah pejal yang masih menggunakan tungku pembakaran dengan bahan bakar kayu. Hal ini sangat jauh berbeda dengan proses pembuatan bata merah pejal di Eropa, Kanada, Amerika,

\begin{tabular}{|lcr|}
\hline Irvin Devanty & Irza Ahmad & Daryati \\
Lulusan Jurusan Teknik Sipil & Staf Pengajar Jurusan Teknik Sipil & Staf Pengajar Jurusan Teknik Sipil \\
Fakultas Teknik & Fakultas Teknik & Fakultas Teknik \\
Universitas Negeri Jakarta & Universitas Negeri Jakarta & Universitas Negeri Jakarta
\end{tabular}


Australia yang sudah menggunakan proses pabrikasi.

Pada industri bata merah proses pembuatannya meliputi beberapa tahapan, antara lain: Tahap pengambilan bahan baku, tahap pembentukan atau pencetakan, tahap pengeringan dan tahap pembakaran.

Dalam proses pembakarannya bata merah tersusun atas beberapa lapisan, serta dilihat dari proses pembakarannya sendiri yang masih menggunakan kayu bakar maka dapat dikatakan panas yang diterima oleh setiap lapisan bata tidak sama, mulai dari lapisan dekat sumber api maupun lapisan yang jauh dari sumber api. Bata merah yang baik mutunya sangat dipengaruhi oleh temperatur pembakaran. Dari beberapa penelitian yang pernah dilakukan pada pembakaran di kantong api (box Fire) hingga $1200^{\circ} \mathrm{C}$. Susunan bata merah pada lapisan atas mendapat temperatur pembakaran $600^{\circ} \mathrm{C}$, lapisan tengah $850^{\circ} \mathrm{C}$ dan lapisan paling bawah $900^{\circ} \mathrm{C}$, Sedang temperatur ideal menurut Balai Industri Banda Aceh berkisar pada $800-$ $900^{\circ} \mathrm{C}$. Seiring dengan perkembangan ilmu pengetahuan dan teknologi dewasa ini banyak bermunculan bahan bangunan untuk konstruksi dinding, namun bata merah memiliki kelebihan tersendiri bila dibandingkan dengan yang lainnya, sehingga masyarakat sebagian besar masih cenderung memilih bata merah sebagai bahan pembuatan dinding suatu bangunan. Dindingdinding bangunan dari segi fisika bangunan mengemban beberapa fungsi diantaranya adalah sebagai pemikul beban.

Banyak hal yang dapat mempengaruhi kekuatan bata merah. Pemilihan bahan dasar dalam pembuatan bata merah perlu diperhatikan, mengingat hal ini berpengaruh pada mutu serta keawetan bata merah yang akan dihasilkan. Dengan adanya pemilihan bahan dasar yang tepat diharapkan akan mengurangi kemungkinan timbulnya pengaruh yang merugikan, serta diharapkan dapat meningkatkan kekuatan dan keawetan bata merah nantinya.

Didalam pembuatan bata merah itu diperlukan bahan baku tanah liat atau lempung, pasir, semen merah dan air. Tanah liat itu sendiri merupakan produk yang berasal dari bebatuan, besar butirnya lebih kecil dari $2 \mu \mathrm{m}$. Jenis tanah ini merupakan tanah yang kurang begitu baik, mereka sukar melangsungkan air dan mudah ditekan, sehingga dengan demikian dapat terjadi penurunan yang berarti.

Dilihat dari adanya penurunan yang terjadi pada tanah liat jika diberikan pembebanan maka penulis berasumsi bahwa penurunan (displacement) juga dapat terjadi pada bata merah jika diberikan pembebanan, namun pembebanan yang dimaksud disini merupakan gaya lateral yang terjadi pada pasangan dinding bata jika terjadi gempa. 
Berdasarkan perumusan di atas, maka dapat dirumuskan masalah sebagai berikut: Adakah perbedaan tingkat penurunan (displacement) akibat pembebanan pada bata merah pejal posisi pembakaran di lapisan atas, tengah dan bawah.

Hasil penelitian ini diharapkan dapat memberi manfaat dan berguna serta menambah wawasan sehingga dapat dijadikan masukan dalam pengembangan industri bata merah, serta dapat dijadikan masukan betapa pentingnya dinding yang selama ini berfungsi sebagai penyekat. Juga dapat menjadi masukan dalam merencanakan suatu struktur dinding pada bangunan bertingkat tinggi maupun rendah, sehingga kenyamanan penghuni atau pemilik menjadi lebih terjamin dengan kualitas yang direncanakan.

Tujuan penelitian ini adalah untuk mengetahui berapa besar perbedaan nilai penurunan (displacement) yang terjadi pada bata merah pejal posisi pembakaran atas, tengah dan bawah jika diberi gaya lateral.

\section{METODE PENELITIAN}

Berdasarkan tujuan penelitian di atas, maka metode penelitian ini adalah metode eksperimen. Populasi dalam penelitian ini adalah bata merah pejal yang diproduksi di daerah Cikarang dari masing-masing posisi pembakaran atas, tengah dan bawah. Jumlah keseluruhan populasi benda uji adalah 80 .

Sampel dalam penelitian ini diambil secara acak, untuk pengujian bata merah pejal yang sampai hancur masing-masing kelompok 10 buah benda uji adapun perinciannya adalah sebagai berikut :

a. Bata merah pejal posisi pembakaran atas berjumlah 10 buah benda uji.

b. Bata merah pejal posisi pembakaran tengah berjumlah 10 buah benda uji.

c. Bata merah pejal posisi pembakaran bawah berjumlah 10 buah benda uji.

d. Untuk pengujian bata merah pejal yang tidak sampai hancur digunakan 10 benda uji. Jadi jumlah keseluruhan sampel yang diuji sebanyak 40 buah.

Pelaksanaan penelitian ini terbagi menjadi dua bagian, yaitu :

1. Pengujian bata merah pejal yang sampai hancur

Adapun prosedur pelaksanaan penelitian ini adalah :

a. Bata merah pejal diberi tanda sesuai dengan kelompoknya masing-masing. 
b. Lakukan pengukuran untuk mengetahui luas dari bidang tekan dengan mengggunakan mistar gulung, catat pada formulir pengujian.

c. Timbang berat dari masing-masing benda uji.

d. Kaping permukaan atas dan bawah benda uji.

e. Setelah kapingan kering, letakkan benda uji pada alat uji tekan, jepit kedua sisi atasnya dengan menggunakan alat bantu yang terhubung dengan dial.

f. Atur jarum penunjuk beban serta jarum pada dial pada posisi nol.

g. Lakukan pembebanan secara bertahap dengan kecepatan konstan, dimulai dari beban $100 \mathrm{~kg}, 200 \mathrm{~kg}, 300 \mathrm{~kg}, 300 \mathrm{~kg}, 400 \mathrm{~kg}, 500 \mathrm{~kg}$ sampai bata tersebut hancur.

h. Catat nilai penurunan setiap kenaikan beban (setiap kali beban ditambah).

i. Catat nilai beban hancur.

j. Hitung kuat hancur dari bata tersebut sesuai dengan rumus dan catat nilai hasil perhitungan pada formulir pengujian, adapun rumus yang digunakan untuk menghitung kuat hancur dari bata merah pejal yang telah diuji adalah :

$$
\sigma=\frac{\mathrm{P}}{\mathrm{A}}
$$

Keterangan :

$\sigma \quad=$ Kuat takan bata merah pejal $\left(\mathrm{kg} / \mathrm{cm}^{2}\right)$

$\mathrm{P} \quad=$ Beban uji maksimum $(\mathrm{kg})$

$A=$ Luas permukaan bidang tekan benda uji $\left(\mathrm{cm}^{2}\right)$

2. Pengujian bata merah pejal yang tidak sampai hancur Adapun pelaksanaan pengujian ini adalah :

a. Beri tanda pada bata merah pejal sesuai dengan kelompoknya masing-masing.

b. Lakukan penimbangan serta pengukuran benda uji untuk mengetahui luas dari bidang tekan benda uji dengan menggunakan mistar gulung, catat pada formulir pengujian.

c. Kaping permukaan atas dan bawah benda uji.

d. Letakkan benda uji pada alat uji tekan, jepit kedua sisinya dengan menggunakan alat Bantu yang terhubung dengan dial secara langsung.

e. Atur jarum penunjuk beban serta jarum dial pada posisi nol. 
f. Lakukan pembebanan secara bertahap dengan kecepatan konstan, dimulai dari beban $100 \mathrm{~kg}, 200 \mathrm{~kg}, 300 \mathrm{~kg}, 400 \mathrm{~kg}, 500 \mathrm{~kg}$ naik terus secara bertahap sampai pada beban $1000 \mathrm{~kg}$, kemudian lakukan penurunan beban secara bertahap dengan cara dikurangi $100 \mathrm{~kg}$ sampai dengan nol.

g. Catat setiap penurunan (displacement)yang terjadi pada saat penambahan beban dan pada saat pengurangan beban pada formulir pengujian.

Untuk pengujian bata merah pejal yang tidak sampai hancur hanya dilihat pada perilaku dari bata merah pajal tersebut dan tidak diadakan uji statistik.

\section{HASIL DAN PEMBAHASAN}

\section{Uji Normalitas}

Data yang dianalisa adalah data nilai penurunan (displacement) bata merah pejal dari masingmasing perlakuan yaitu perlakuan A (posisi pembakaran atas), perlakuan B (posisi pembakaran tengah) dan perlakuan $\mathrm{C}$ (posisi pembakaran bawah).

\section{Hasil Uji Normalitas Penurunan Bata Merah Pejal Posisi Pembakaran Atas}

Hasil pengujian normalitas dari data nilai penurunan (displacement) bata merah pejal posisi pembakaran atas, menghasilkan Lohitung $=0,2628$, pada taraf signifikan $(\alpha)=0,01$ diperoleh $L_{\text {tabel }}=0,2940$, dengan kriteria pengujian apabila $L_{\text {hitung }}<L_{\text {tabel }}$ maka data berdistribusi normal, dengan demikian dapat disimpulkan bahwa populasi kelompok berdistribusi normal.

Rangkuman uji normalitas nilai penurunan bata merah pejal posisi pembakaran atas dapat dilihat pada tabel 1. berikut :

Tabel 1. Uji Normalitas Penurunan Bata Merah Pejal Posisi Pembakaran Atas

\begin{tabular}{|l|c|c|c|}
\hline \multicolumn{1}{|c|}{ Subjek } & Lo hitung $_{\text {tabel }}$ & Hasil \\
\hline Bata merah pejal & & & LOhitung $<L_{\text {tabel }}$ \\
$\begin{array}{l}\text { Posisi Pembakaran } \\
\text { Atas }\end{array}$ & 0,2628 & 0,2940 & Distribusi normal \\
\hline
\end{tabular}

\section{Hasil Uji Normalitas Penurunan Bata Merah Pejal Posisi Pembakaran Tengah}

Hasil pengujian normalitas dari data nilai penurunan (displacement) bata merah pejal posisi pembakaran tengah menghasilkan Lohitung $=0,2483$, pada taraf signifikan $(\alpha)=0,01$ 
diperoleh $L_{\text {tabel }}=0,2940$, dengan kriteria pengujian apabila $L_{\text {Ohitung }}<L_{\text {tabel }}$ maka data berdistribusi normal, dengan demikian dapat disimpulkan bahwa populasi kelompok berdistribusi normal. Rangkuman uji normalitas nilai penurunan (displacement) bata merah pejal posisi pembakaran tengah dapat dilihat pada tabel 2. berikut :

Tabel 2. Uji Normalitas Penurunan Bata Merah Pejal Posisi Pembakaran Tengah

\begin{tabular}{|l|c|c|c|}
\hline Subjek & Lohitung & L $_{\text {tabel }}$ & Hasil \\
\hline $\begin{array}{l}\text { Bata merah pejal Posisi } \\
\text { Pembakaran Tengah }\end{array}$ & 0,2483 & 0,2940 & $\begin{array}{c}\text { LOhitung }<\text { Ltabel } \\
\text { Distribusi normal }\end{array}$ \\
\hline
\end{tabular}

\section{Hasil Uji Normalitas Penurunan Bata Merah Pejal Posisi Pembakaran Bawah}

Hasil pengujian normalitas dari data nilai penurunan (displacement) bata merah pejal posisi pembakaran bawah menghasilkan LOhitung $=0,1578$ pada taraf signifikan $(\alpha)=0,01$ diperoleh $L_{\text {tabel }}=0,2940$, dengan kriteria pengujian apabila $L_{\text {hitung }}<L_{\text {tabel }}$ maka data berdistribusi normal, dengan demikian dapat disimpulkan bahwa populasi kelompok berdistribusi normal. Rangkuman uji normalitas nilai penurunan (displacement) bata merah pejal posisi pembakaran bawah dapat dilihat pada tabel 3 berikut :

Tabel 3. Uji Normalitas Penurunan Bata Merah Pejal Posisi Pembakaran Bawah

\begin{tabular}{|l|c|c|c|}
\hline Subjek & Lohitung & Ltabel & Hasil \\
\hline $\begin{array}{l}\text { Bata merah pejal } \\
\begin{array}{l}\text { Posisi Pembakaran } \\
\text { Bawah }\end{array}\end{array}$ & 0,1578 & 0,2940 & Lo hitung $<L_{\text {tabel }}$ \\
\hline
\end{tabular}

\section{Uji Homogenitas}

Analisa statistik yang digunakan unttuk menguji homogenitas adalah uji Barlet. Data yang diuji adalah data nilai penurunan (displacement)dari masing-masing kelompok sampel. Dari perhitungan diperoleh $\chi^{2}$ hitung $=2,254$, jika taraf nyata $(\alpha)=0,01$ dari daftar chi kuadrat denga $\mathrm{dk}=3$ didapat $\chi^{2}$ tabel $=11,3$ sehingga $\chi^{2}$ hitung $<\chi^{2}$ tabel, maka dapat disimpulkan varians dari ketiga kelompok homogen. Rangkuman uji homogenitas dari nilai penurunan (displacement) bata merah pejal posisi pembakaran atas, tengah dan bawah dapat dilihat pada tabel 4 berikut: 
Tabel 4 Uji Homogenitas

\begin{tabular}{|c|c|l|}
\hline $\boldsymbol{\chi}^{2}$ hitung & $\boldsymbol{\chi}^{2}{ }_{\text {tabel }}$ & Hasil \\
\hline 2,254 & 11,3 & $\begin{array}{l}\boldsymbol{\chi}^{2} \text { hitung } \\
\text { data } \boldsymbol{\chi}^{2} \text { tabel }\end{array}$ \\
\hline
\end{tabular}

\section{Pengujian Hipotesis}

Untuk mengetahui adanya perbedaan nilai peneurunan (displacement) bata merah pejal posisi pembakaran atas, tengah dan bawah digunakan Uji Analisis Varians (ANAVA). Dengan kriteria tolak $\mathrm{H}_{0}$ jika $\mathrm{F}_{\text {hitung }}>\mathrm{F}_{\text {tabel }}$ atau terima $\mathrm{H}_{1}$ jika $F_{\text {hitung }}>\mathrm{F}_{\text {tabel. }}$.

Dari hasil pengujian dengan menggunakan uji ANAVA, didapat $F_{\text {tabel }}=5,49$ dengan taraf signifikan $(\alpha)=0,01$, dk pembilang $=2$, dk penyebut $=27$ dan peluang 0,99 . Sedangkan dari perhitungan didapat $F_{\text {hitung }}=17,65$, jadi $F_{\text {hitung }}>F_{\text {tabel, }}$ maka $H_{0}$ ditolak dalam taraf signifikan 0,01 . sehingga terbukti bahwa ada perbedaan yang signifikan dalam hal nilai penurunan (displacement) bata merah pejal posisi pembakaran atas, tengah dan bawah. Rangkuman hasil uji ANAVA dapat dilihat pada tabel berikut :

Tabel Hasil Uji Analisis Varians (ANAVA)

\begin{tabular}{|l|c|c|c|c|c|}
\hline Sumber Variansi & Dk & $\mathbf{J k}$ & $\mathbf{K t}$ & $\mathbf{T}_{\text {hitung }}$ & $\mathbf{T}_{\text {tabel }}$ \\
\cline { 1 - 4 } Rata-rata & 1 & 541,875 & 541,875 & & \\
\cline { 1 - 4 } Antar kelompok & 2 & 25,062 & 12,531 & & \multirow{2}{*}{17,65} \\
\cline { 1 - 4 } Dalam kelompok & 27 & 19,213 & 0,71 & & \\
\cline { 1 - 3 } Jumlah & 30 & 586,15 & - & & \\
\hline
\end{tabular}

\section{Pembahasan}

Dilihat dari hasil penelitian bahwa antara nilai penurunan (displacement) bata merah pejal posisi pembakaran atas, tengah dan bawah terdapat perbedaan yang signifikan. Pada bata merah pejal posisi pembakaran atas didapat nilai penurunan (displacement) yang besar dengan nilai penurunan rata-rata $5,16 \mathrm{~mm}$ dan nilai kuat hancurnya rata-rata $44,654 \mathrm{~kg} / \mathrm{cm} 2$.

Pada bata merah pejal posisi pembakaran tengah didapat nilai penurunan (displacement) yang kecil dengan nilai penurunan rata-rata $3,00 \mathrm{~mm}$ dan nilai kuat 
hancurnya rata-rata $66,949 \mathrm{~kg} / \mathrm{cm} 2$. Pada bata merah pejal posisi pembakaran bawah didapat nilai penurunan (displacement) rata-rata 4,49 dan nilai kuat hancurnya rata-rata $49,511 \mathrm{~kg} / \mathrm{cm} 2$

Dari data-data tersebut di atas dapat dilihat bata merah pejal posisi pembakaran atas mempunyai nilai kuat hancur yang paling kecil dengan nilai penurunan (displacement) yang paling besar, kekuatan bata merah pejal posisi pembakaran atas tergolong kecil sehingga mudah terjadi penurunan yang bila diberikan pembebanan, sedangkan untuk bata merah pejal posisi pembakaran tengah mempunyai nilai kuat hancur yang terbesar dengan nilai penurunan yang terkecil, kekuatan bata merah pejal posisi pembakaran tengah tergolong besar sehinggga tidak mudah terjadi penurunan yang berarti bila diberi pembebanan. Untuk bata merah pejal posisi pembakaran bawah nilai penurunan dan nilai kuat hancurnya terletak diantara bata merah pejal posisi pembakaran atas dan bata merah pejal posisi pembakaran tengah.

\section{KESIMPULAN}

Dari hasil penelitian yang telah dilakukan maka dapat ditarik kesimpulan sebagai berikut :

\section{Bata Merah Pejal yang Sampai Hancur}

Hasil penelitian yang diperoleh pada bata merah pejal yang sampai hancur adalah sebagai berikut :

(a) Terdapat perbedaan yang signifikan dalam hal penurunan (displacement) bata merah pejal posisi pembakaran atas dengan bata merah pejal posisi pembakaran tengah dan bata merah pejal posisi pembakaran bawah.

(b) Nilai penurunan (displacement) bata merah pejal posisi pembakaran tengah dengan suhu pembakaran $850^{\circ} \mathrm{C}$, lebih kecil dari nilai penurunan (displacement) bata merah pejal posisi pembakaran bawah, dengan suhu pembakaran $900^{\circ} \mathrm{C}$. Sedangkan untuk bata merah pejal posisi pembakaran atas dengan suhu pembakaran $600^{\circ} \mathrm{C}$ memiliki nilai penurunan (displacement) yang terbesar.

(c) Bata merah pejal yang dibakar pada posisi pembakaran tengah dan bawah tungku memiliki ukuran lebih kecil dibandingkan dengan bata merah pejal posisi pembakaran atas. Hal ini disebabkan oleh besar suhu yang diterima. 
(d) Bata merah pejal posisi pembakaran tengah mempunyai nilai penurunan (dispacement) yang paling kecil dengan nilai kuat hancur yang terbesar karena temperatur yang ideal tidak terlalu panas dan tidak juga kurang suhunya.

\section{Bata Merah Pejal yang Tidak Sampai Hancur}

Hasil dari penelitian bata merah pejal yang tidak sampai hancur adalah sebagai berikut :

(a) Nilai penurunan (displacement) bata merah pejal posisi pembakaran atas yang diberi pembebanan secara berulang ternyata lebih besar dari nilai penurunan bata merah pejal posisi pembakaran tengah dan bawah.

(b) Untuk nilai penurunan (displacement) bata merah pejal pada posisi pembakaran tengah dengan bata merah pejal pada posisi pembakaran bawah ternyata hasilnya tidak jauh berbeda. Hal ini disebabkan perbedaan panas yang diterima tidak terlalu berbeda.

(c) Bata merah pejal posisi pembakaran tengah mempunyai nilai penurunan (dispacement) yang paling kecil dengan nilai kuat hancur yang terbesar karena temperatur yang ideal tidak terlalu panas dan tidak juga kurang suhunya.

(d) Ukuran bata merah pejal pada posisi pembakaran tengah dan bawah lebih kecil dibandingkan dengan bata merah pejal posisi pembakaran atas

\section{DAFTAR PUSTAKA}

Balai Penelitian Bahan, Petujuk Teknis Proses Pembuatan Bata merah pejal, （Jakarta: Balai Penelitian Bahan, 1978)

Kwantes, J, Ilmu Bangunan I, (Jakarta: Erlangga,1987)

Mangunwijaya, Y.B, Pasal-Pasal Penghantar Fisika Bangunan, (Jakarta: PT Gramedia 1981)

Mutu, Kiyoshi, Analisis Perencanaan Gedung Tahan Gempa, (Jakarta: Erlangga 1993)

Ritonga, S.M, Bahan Bangunan, (Bandung: DPU, 1982)

Smith, M.J, Bahan Konstruksi dan Stuktur Teknik, (Jakarta: Erlangga, 1985)

SNI 15-2094-2000, Bata Merah Pejal Untuk Pasangan Dinding, (Jakarta: BSN, 2001)

Soraya, et.all, Aspek Tekno Ekonomi Batu Bara Sebagai Energi Alternatif Pada Industri Pembakaran Batu Bata, (Universitas Syah Kuala Banda Aceh, 1998) 
Sudjana, Metode Statistika, (Bandung: Tarsito, 1996)

Wang, R, Numerical Study of Tall Masonry Cavity Walls Subjected To Eccentric Load, (Journal of Structural Enineering, 1997)

Wesley, L.D, Mekanika tanah, (Jakarta: Badan Penerbit Pekerjaan Umum, 1972) 